\title{
Rhodosporidium paludigenum sp. nov., a Basidiomycetous Yeast from Intertidal Waters of South Florida
}

\author{
JACK W. FELL AND ADELE STATZELL TALLMAN \\ Rosenstiel School of Marine and Atmospheric Science, University of Miami, Miami, Florida 33149
}

Rhodosporidium paludigenum sp. nov. has the phenotypic characteristics of the imperfect yeast Rhodotorula graminis and a bipolar incompatibility mating system, and is not sexually compatible with other Rhodosporidium species. The type strain of this new species is CBS 6566.

Sexuality in the genus Rhodotorula Harrison was first reported by Banno (1) with the description of Rhodosporidium toruloides Banno 1967. The genus has since been expanded to include eight species (2). During a review of the genus for a new edition (Kreger-van Rij, in preparation) of The Yeasts, a Taxonomic Study (3), we examined a previously undescribed species from intertidal waters of south Florida in mangrove (Rhizophora mangle L.) swamps and black rush (Juncus roemerianus Scheele) marshes. The imperfect stage of this yeast has the characteristics of Rhodotorula graminis di Menna 1958, which is differentiated from other members of the genus Rhodotorula by the ability to assimilate nitrate (as $\mathrm{KNO}_{3}$ ) as a sole source of nitrogen and the inability to utilize melezitose as a sole source of carbon (4). These isolates of $R$. graminis from intertidal sources were found to have a basidiomycetous life cycle when they were mixed on corn meal agar. The life cycle is heterothallic; cells from opposite mating types conjugated with the development of mycelia with clamp connections and round teliospores. The teliospores germinated to produce septate metabasidia with lateral and terminal basidiospores. We isolated the basidiospores by micromanipulation, followed by culturing and mating studies, and found only the parental mating types. This indicates that sexuality consists of a bipolar incompatibility system (5).

Rhodosporidium malvinellum Fell et Hunter 1970 is the only other species of Rhodosporidium with the phenotypic characteristics of Rhodotorula graminis. Rhodosporidium malvinellum and the new species are distinct, as suggested by differences in their colony colors: Rhodosporidium malvinellum has a distinct mauve color in contrast to the salmon-orange color of the new species. The species distinction is confirmed by mating experiments which demonstrate that the two species do not intermate. Neither Rhodosporidium malvinellum nor the new species mates with the type strain of Rho- dotorula graminis (CBS 2826), suggesting that the imperfect state of Rhodotorula graminis represents more than two sexual species. A similar situation is present with Rhodotorula glutinis (Fres.) Harrison 1852, which consists of three sexual species (Rhodosporidium sphaerocarpum Newell et Fell 1970, Rhodosporidium toruloides, and Rhodosporidium diobovatum Newell et Hunter 1970).

Using the recommended techniques reviewed by Van der Walt (6), the new species is described as follows.

Rhodosporidium paludigenum sp. nov.

Etymology. L. neut. adj. paludigenum, swamp-born; i.e., coming from the swamp.

Growth in malt extract. After 3 days at $25^{\circ} \mathrm{C}$, the cells are oval to elongate $(2$ to 4 by 3 to $11 \mu \mathrm{m}$ ). They occur singly and in pairs. There is a light sediment. After 1 month, there is a heavy ring with a light to heavy sediment.

Growth on malt agar. After 3 days at $25^{\circ} \mathrm{C}$, the cell morphology is similar to that in malt extract. The 1-month-old streak culture is salmon orange, smooth, glistening, and slightly raised or rugose; the border is entire.

Dalmau cultures on corn meal agar. After 6 days at $25^{\circ} \mathrm{C}$, there are short chains of budding cells; short lengths of true mycelium may be present.

Life history. When opposite mating types were mixed on corn meal agar (prepared with $20 \%$ seawater) and incubated at 22 to $25^{\circ} \mathrm{C}$, a true mycelium bearing spheroidal (13 to $17 \mu \mathrm{m}$ in diameter) teliospores developed within 6 days. The teliospores were in clusters of two to four and were intercalary; rarely were they terminal on the mycelium. Teliospore germination (Fig. 1) after 4 weeks on corn meal agar resulted in two- to four-celled metabasidia. Basidiospores were of the two parental types, indicating a bipolar sexual system. Rhodosporidium paludigenum does not mate with the other species included in the genus (2).

Characteristics. Fermentation, - . Assimila- 


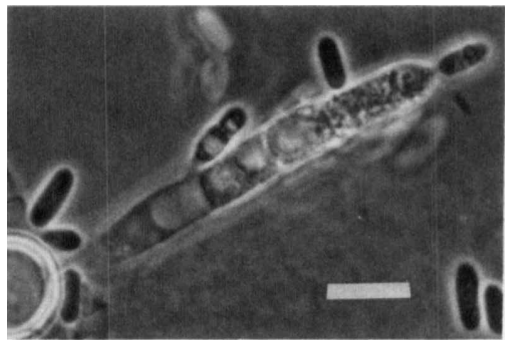

FIG. 1. Teliospore, phragometabasidium, and basidospores of Rhodosporidium paludigenum. Bar, 10 $\mu \mathrm{m}$.

tion of carbon compounds was as follows $(\mathrm{L}=$ latent, $\mathrm{w}=$ weak): galactose, + ; sucrose, + ; maltose, $+\mathrm{L}$; cellobiose, +; trehalose, $+\mathrm{L}$; lactose, -; melibiose, -; raffinose, +; melezitose, - ; soluble starch, -; D-xylose, +L; L-arabinose, +L; Dribose, $+\mathrm{L}$; L-rhamnose, $+\mathrm{L}$; erythritol, - ; ribitol, +; galactitol, +; D-mannitol, +; $\alpha$-methyl-Dglucoside, - ; succinic acid, $+w$; citric acid, $+w$; inositol, - Assimilation of nitrate, + ; growth in vitamin-free medium, +; growth on $50 \%(\mathrm{wt} / \mathrm{wt}$ ) glucose-yeast extract agar, -; growth at $37^{\circ} \mathrm{C}$, -; starch formation, -; urease, +; diazonium blue $B$ reaction, + .

Origin of the strains studied. Two strains (CBS 6565 and CBS 6567, both mating type A1) were from a mangrove swamp (Rhizophora mangle). A third strain (CBS 6566, mating type A2) was from a black rush (Juncus roemerianus) marsh. These strains were collected April 1973 from intertidal waters of Card Sound near Miami, Fla., and cultures of them have been deposited in the Centraalbureau voor Schimmelcultures, Delft, The Netherlands. Type strain: CBS-6566. Allotype strain: CBS-6567.
The Latin diagnosis of this new species is as follows: Hyphae secundum copulationem cellularum (binucleatal). Teliosporae intercalares, terminales, sphaericae. Metabasidia bicellularis aut tetracellularis. Fermentatio nulla. Galactosum, sucrosum, maltosum, cellobiosum, trehalosum, raffinosum, D-xylosum, L-arabinosum, Dribosum, L-rhamnosum, ribitolum, D-mannitolum assimilantur, at non lactosum, erythritolum, inositolum, nec melezitosum. Kalium nitricum assimilatur. Typus CBS 6566. Allotypus CBS 6567.

\section{ACKNOWLEDGMENT}

This research was funded by the National Science Foundation through the Office of Systematic Biology, grant no. DEB-7912190.

\section{REPRINT REQUESTS}

Address reprint requests to: Dr. Jack W. Fell, Rosenstiel School of Marine and Atmospheric Science, University of Miami, 4600 Rickenbacker Causeway, Miami, FL 33149.

\section{LITERATURE CITED}

1. Banno, I. 1967. Studies on the sexuality of Rhodotorula. J. Gen. Appl. Microbiol. 13:167-196.

2. Fell, J. W., I. L. Hunter, and A. S. Tallman. 1973. Marine basidiomycetous yeasts (Rhodosporidium spp. n.) with tetrapolar and multiple allelic bipolar mating systems. Can. J. Microbiol. 19:643-657.

3. Lodder, J. 1970. The yeasts, a taxonomic study, 2nd ed. North Holland Publishing Co., Amsterdam.

4. Phaff, H. J., and D. G. Ahearn. 1970. 'The genus Rhodotorula Harrison, p. 1187-1223. In J. Lodder (ed.), The yeasts, a taxonomic study, 2nd ed. North Holland Publishing Co., Amsterdam.

5. Raper, J. R. 1966. Genetics of sexuality in higher fungi. Ronald Press, New York.

6. Van der Walt, J. P. 1970. Criteria and methods used in classification, p. 34-113. In J. Lodder (ed.), The yeasts, a taxonomic study, 2nd ed. North-Holland Publishing Co., Amsterdam. 